\title{
PHBS Pada Masa Pandemi Covid-19 Untuk Mendukung Gaya Hidup Sehat Masyarakat Di Rw 05 Kelurahan Kampung Dalam Kecamatan Senapelan Kota Pekanbaru
}

\author{
Chairil, Nadhira Hilwa \\ Fakultas MIPA dan Kesehatan \\ Universitas Muhammadiyah Riau \\ email: chairil@umri.ac.id
}

\begin{abstract}
The spread of Covid-19 has now become a pandemic outbreak in Indonesia. The emergence of this disease outbreak encourages the importance of implementing PHBS. Implementing PHBS properly can help prevent Covid-19 and support a healthy lifestyle during this Covid-19 pandemic. Objective: To find out the description of Clean and Healthy Lifestyle (PHBS) during the Covid-19 pandemic to support a healthy lifestyle. The method used was the counseling lecture for 6-8 people. It was held from September 10 to September 20 in RW 05, Kampung Village in Senapelan District, Pekanbaru City. This population amounted to 203 families with the number of samples taken partly from the total population with the number of respondents used was 67 respondents. The sampling technique used is the Simple Random Sampling technique. The instrument used is a questionnaire. The results of the service in the category of good PHBS are 35 respondents (52.2\%), while people who have poor PHBS are 32 respondents (47.8\%). Conclusion: More efforts are needed for cooperation in RW 05, Kampung Village in Senapelan Subdistrict, Pekanbaaru City, that the community currently does not understand PHBS during the pandemic.
\end{abstract}

Keywords: PHBS, Covid-19, Public

\begin{abstract}
Abstrak
Penyebaran Covid-19 kini telah menjadi wabah pandemi di Indonesia.Munculnya wabah penyakit ini mendorong pentingnya untuk menerapkan PHBS. Penerapan PHBS dengan baik dapat membantu pencegahan Covid-19 dan mendukung gaya hidup sehat pada masa pandemi Covid-19 ini. Tujuan: Untuk mengetahui gambaran Perilaku Hidup Bersih Dan Sehat (PHBS) pada masa pandemi Covid19 untuk mendukung gaya hidup sehat. Metode yang di gunakan cerama penyuluhan 6-8 orang ini dilaksanakan pada tanggal 10 September s/d 20 September di RW 05 Kelurahan Kampung dalam Kecamatan Senapelan Kota Pekanbaru. Populasi ini berjumlah 203 KK dengan jumlah sampel yang diambil sebagian dari jumlah populasi dengan jumlah responden yang digunakan adalah 67 responden. Teknik pengambilan sampel yang digunakan adalah teknik Simple Random Sampling. Instrumen yang digunakan adalah kuesioner.hasil dari pengabdian dalam kategori PHBS yang baik sebanyak 35 responden (52.2\%), sedangkan masyarakat yang memiliki PHBS yang buruk ada 32 responden (47.8\%). Kesimpulan : Perlu upaya yang lebih lagi untuk kerjasam di RW 05 Kelurahan Kampung dalam Kecamatan senapelan Kota Pekanbaaru bahwa masyarakat saat ini belum memahami dengan PHBS pada masa pendemi.
\end{abstract}

Kata Kunci: PHBS, Covid-19, Masyarakat

\section{PENDAHULUAN}

Penyebaran Corona Virus Disease 2019 (Covid-19) kini telah menjadi wabah pandemi di Indonesia. Mewabahnya penyebaran penyakit ini menyebabkan bencana bagi masyarakat hingga mengakibatkan kematian ribuan jiwa di seluruh dunia, tak terkecuali di Indonesia. Munculnya wabah penyakit ini mendorong pentingnya untuk menerapkan Perilaku Hidup Bersih dan Sehat (PHBS) (Mulyadi, H, 2020). 
Perilaku Hidup Bersih dan Sehat (PHBS) adalah sekumpulan perilaku yang dipraktikkan atas dasar kesadaran sebagai hasil pembelajaran, yang menjadikan seseorang, keluarga, kelompok atau masyarakat mampu menolong dirinya sendiri (mandiri) di bidang kesehatan dan berperan aktif dalam mewujudkan kesehatan masyarakat (Kemkes RI, 2011).

Perilaku Hidup Bersih dan Sehat (PHBS) merupakan salah satu strategi dalam pencegahan penyebaran Covid-19 yang sangat efektif dan mudah dilakukan oleh semua lapisan masyarakat. Kurangnya kesadaran masyarakat terhadap Perilaku Hidup bersih dan Sehat (PHBS) menjadi salah satu penyebab sulitnya memutus rantai penularan virus Covid-19 (Tria Anggraini \& Hasibuan, 2020).

Secara global, pada 21 Maret 2021 ada 122.524.424 kasus Covid-19 yang terkonfirmasi, termasuk 2.703.620 kematian, di laporkan ke WHO. Ada tiga benua yang terkonfirmasi Covid-19 paling tinggi yaitu Benua Amerika dengan 53.937.714 kasus, Benua Eropa 42.504.449 kasus, dan Benua Asia Tenggara 14.182.826 kasus (WHO, 2021).

Di Indonesia sekitar 1.465.928 kasus terkonfirmasi terjangkit virus Covid-19 yang telah dilaporkan pada tanggal 22 Maret 2021, termasuk sekitar 39.711 orang meninggal dunia dan pasien Covid-19 yang dinyatakan sembuh 1.297.967 orang (KemenkesRI, 2021). Provinsi Riau, pada tanggal 21 maret 2021 jumlah kasus mencapai 32.791 kasus terkonfirmasi positif Covid-19, di nyatakan sembuh 30.910 dan 801 kematian di Riau. Kota Pekanbaru menjadi penyumbang terbanyak kasus positif Covid-19 di Riau dengan mencapai 34 kasus positif covid-19 dan Kabupaten Kampar mencapai 10 kasus positif Covid-19 (Dinas kesehatan provinsi riau, 2021).

Perilaku Hidup Bersih dan Sehat (PHBS) merupakan salah satu bentuk dari perilaku sehat. Perilaku sehat merupakan respon yang dilakukan oleh individu untuk memelihara dan meningkatkan kesehatan.
Menurut Becker, perilaku sehat terbentuk dari tiga domain yang mengacu pada domain pendidikan taksonomi Bloom. Domain tersebut terdiri dari pengetahuan, sikap dan praktik atau tindakan. Pengetahuan adalah hasil dari proses belajar seseorang melalui berbagai panca indera akibat rasa ingin tahu. Sikap adalah respon tertutup seseorang yang dihasilkan akibat rangsangan terhadap stimulus tertentu. Praktik adalah bentuk aplikasi dari pengetahuan dan sikap yang dimiliki oleh seseorang dalam bentuk nyata atau terbuka sehingga dapat dilihat oleh orang lain (Notoatmodjo, 2014). Melalui pengetahuan yang baik diharapkan dapat turut membentuk sikap yang baik sehingga akan membantu terciptanya perilaku kesehatan yang khususnya Perilaku Hidup Bersih dan Sehat (PHBS) yang mandiri (Rusdi et al., 2021).

Tetapi masyarakat tidak perlu khawatir pada masa pandemi Covid-19 ini karena dengan penerapan Perilaku Hidup Bersih dan Sehat (PHBS) yang meliputi menjaga makanan yang bergizi, istirahat yang cukup, dan olahraga teratur karena menjaga imunitas tubuh dapat meningkatkan sistem kekebalan tubuh agar tubuh tetap sehat dan terhindar dari penyakit dan dapat mengendalikan infeksi Covid-19. Proteksi diri dapat dilakukan dengan menggunakan masker, selalu cuci tangan dengan bersih dan jaga pola hidup sehat dan bersih maka mampu mencegah virus masuk kedalam tubuh manusia. Memerangi Covid-19 ini kuncinya adalah menjaga perilaku hidup bersih dan sehat (PHBS), hal ini sangat sederhana namun sangat efektif untuk dilakukan. Salah satunya adalah membiasakan diri mencuci tangan dengan sabun atau hand sanitizer setiap selesai melakukan aktivitas (Karo, 2012). Berdasarkan penjelasan di atas maka tertarik untuk melakukan pengabdian melihat sejauh mana penerapan Perilaku Hidup Bersih dan Sehat (PHBS) pada masa pandemi Covid19 untuk mendukung gaya hidup sehat dan 
menurunkan angka kejadian penularan Covid-19 di masyarakat.

\section{METODE PENGABDIAN}

Kegiatan ini di lakukan dengan cara cerama /penyuluhan kesehatan dengan jumlah 6-8 oarang dilakukan di RW 05 Kelurahan Kampung dalam Kecamatan Senapelan. . Populasi berjumlah 203 KK dengan jumlah sampel yang diambil sebagian dari jumlah populasi dengan jumlah responden yang digunakan adalah 67 responden Teknik pengambilan sampel yang digunakan adalah teknik Simple Random Sampling. Instrumen alat pegara seperti maskes buku baca foster dan kuesioner.

\section{HASIL DAN PEMBAHASAN}

Kegiatan yang telah dilakukan pada bulan September 2021 di RW 05 Kelurahan Kampung dalam Kecamatan Senapelan Kota Pekanbaru dari 67 responden dapat diperoleh data-data mengenai Gambaran Perilaku Hidup Bersih dan Sehat (PHBS) Pada Masa Pandemi Covid-19 Untuk Mendukung Gaya Hidup Sehat Masyarakat sebagai berikut :

\section{a. Karakteristik Responden}

Tabel 4.1 Distribusi Frekuensi Umur Responden Di RW 05 Kelurahan Kampung dalam Kecamatan Senapelan Pekanbaru September 2021

\begin{tabular}{clc}
\hline No & \multicolumn{1}{c}{ Variabel } & Hasil \\
\hline \multirow{2}{*}{1} & Umur & \\
\cline { 2 - 3 } & Mean & 34.91 \\
\cline { 2 - 2 } & Stdr.Devisiasi & 12.556 \\
\cline { 2 - 2 } & Min-Max & $17-65$ \\
\cline { 2 - 3 } & 95\% CI & $31.85-37.97$ \\
\hline
\end{tabular}

Tabel $4.2 \quad$ Distribusi $\quad$ Frekuensi Berdasarkan Jenis Kelamin, Pendidikan, Pekerjaan Responden Di RW 05 Kelurahan Kampung dalam Kecamatan Senapelan Pekanbaru September 2021.

\begin{tabular}{|c|c|c|c|}
\hline \multirow[t]{4}{*}{1} & \multicolumn{3}{|l|}{ Jenis Kelamin } \\
\hline & Laki - Laki & 32 & 47.8 \\
\hline & Perempuan & 35 & 52.2 \\
\hline & Total & 67 & 100 \\
\hline \multirow[t]{5}{*}{2} & Pendidikan & & \\
\hline & Rendah(SD-SMP) & 23 & 34.3 \\
\hline & $\begin{array}{l}\text { Menengah } \\
\text { (SMA/Sederajat) }\end{array}$ & 40 & 59.7 \\
\hline & $\begin{array}{l}\text { Tinggi(Perguruan } \\
\text { Tinggi) }\end{array}$ & 4 & 6.0 \\
\hline & Total & 67 & 100 \\
\hline \multirow[t]{8}{*}{3} & Pekerjaan & & \\
\hline & Pelajar & 1 & 1.5 \\
\hline & Mahasiswa & 4 & 6.0 \\
\hline & IRT & 19 & 28.4 \\
\hline & Pedagang & 22 & 32.8 \\
\hline & Wiraswasta & 9 & 13.4 \\
\hline & Karyawan Swasta & 12 & 17.9 \\
\hline & Total & 67 & 100 \\
\hline
\end{tabular}

\section{b. Data Khusus}

Tabel 4.3 Distribusi Frekuensi Berdasarkan Perilaku Hidup Bersih dan Sehat (PHBS) Responden Di RW 05 Kelurahan Kampung dalam Kecamatan Senapelan Pekanbaru September 2021

\begin{tabular}{clcc}
\hline No & \multicolumn{1}{c}{ PHBS } & F & \% \\
\hline $\mathbf{1}$ & $\begin{array}{l}\text { Baik (Nilai Skor } \geq \\
\text { 9.66) }\end{array}$ & $\mathbf{3 5}$ & $\mathbf{5 2 . 2}$ \\
\hline 2 & $\begin{array}{l}\text { Buruk (Nilai Skor } \\
<9.66)\end{array}$ & 32 & 47.8 \\
\hline \multicolumn{1}{c}{ Total } & $\mathbf{6 7}$ & $\mathbf{1 0 0}$ \\
\hline
\end{tabular}

\section{SIMPULAN}

Perlu upaya yang lebih lagi untuk kerjasam di RW 05 Kelurahan Kampung dalam Kecamatan senapelan Kota Pekanbaaru bahwa masyarakat saat ini perlu edukasi memahami PHBS pada masa pendemi hal ini bentuk yang di lakukan sebagai impelemtasi berupa pengandian masayarakat dapat memberikan pemahama PHBS di masa pendemi

\begin{tabular}{llll}
\hline No & Variabel & f & $\%$ \\
\hline
\end{tabular}




\section{UCAPAN TERIMAKASIH}

Terima kasih kepada lembaga penelitian dan pengabdian umri yang telah membantu dalam hal surat dan adimtrasi serta pak RT 05 kampung dalam Kelurahan kampong dalam Kecamatan senapelan kota pekanbaru dan masyarakat setempat

\section{DAFTAR PUSTAKA}

[1]. Antari, N. P. U., Dewi, N. P. K., Putri, K. A. K., Rahayu, L. R. P., Wulandari, N. P. N. K., Ningsih, N. P. A. W., Pertiwi, N. W. A., Cahyanti, N. P. S. D. C., Damayanti, M. E. A., Dewi, M. T. L., Candrayani, K. T., \& Jati, G. B. K. A. (2020). Perilaku Hidup Bersih Dan Sehat Mahasiswa Universitas Mahasaraswati Denpasar Selama Pandemi Covid-19. Jurnal Ilmiah Medicamento, 6(2), 94-99. https://doi.org/10.36733/medicamen to.v6i2.1056

[2]. Dinas kesehatan provinsi riau. (2021). Update Covid-19 Provinsi Riau. Riau Tanggap COVID-19. https://corona.riau.go.id/

[3]. Dwi Astuti, F., \& Suryani, D. (2018). Faktor-Faktor yang Berhubungan dengan Perilaku Hidup Bersih dan Sehat pada Pedagang Angkringan di Kawasan Malioboro Yogyakarta. Afiasi: Jurnal Kesehatan Masyarakat, 3(3), 79-86. https://doi.org/10.31943/afiasi.v3i3. 26

[4]. Karo, M. B. (2012). Perilaku Hidup Bersih dan Sehat ( PHBS ) Strategi Pencegahan Penyebaran Virus Covid-19. 1-4.

[5]. Karuniawati, B., \& Berlina Putrianti. (2020). Gambaran Perilaku Hidup Bersih Dan Sehat (PHBS) Dalam Pencegahan Penularan Covid-19.
Jurnal Kesehatan Karya Husada, $8(2)$, 34-53. http://jurnal.poltekkeskhjogja.ac.id/i ndex.php/jkkh/article/view/411

[6]. Kemenkes. (2011). PEDoman Pembinaan Perilaku Hidup Bersih Dan Sehat (PHBS).

[7]. Mulyadi, H, D. (2020). Pentingnya Penerapan PHBS Dalam Menghadapi Pandemi Covid-19 Di Lingkungan Masyarakat. Journal of Chemical Information and Modeling, 1-10.

[8]. Notoatmodjo, S. (2014). Promosi Kesehatan Dan Perilaku Kesehatan. Jakarta : Rineka Cipta.

[9]. Nurmalita. (2016). Hubungan antara Jenis Kelamin, Tingkat Kelas, Pengetahuan, dan Sikap terhadap Perilaku Penggunaan Fasilitas MCK di SDN 01 Kecubung Mulya.

[10]. Prihanti, G. S. (2018). Faktor-Faktor Yang Mempengaruhi Tingkat Perilaku Hidup Bersih Poned X. 714

[11]. Rusdi, M. S., Efendi, M. R., Putri, L. E., \& Kamal, S. (2021). Edukasi Penerapan Perilaku Hidup Bersih dan Sehat ( PHBS ) sebagai Upaya Pencegahan Penyebaran Covid-19. Jurnal Altifani, 1(1), 47-51

[12]. Suen, L. K. P., So, Z. Y. Y., Yeung, S. K. W., Lo, K. Y. K., \& Lam, S. C. (2019). Epidemiological investigation on hand hygiene knowledge and behaviour: A crosssectional study on gender disparity. BMC Public Health, 19(1), 1-14. https://doi.org/10.1186/s12889-0196705 -

[13]. Suwaryo. (2017). Fakto-faktor Yang Mempengaruhi Tingkat Pengetahuan Masyarakat dalam Mitigasi Bencana Alam Tanah Longsor. 2407-9189, 305-314. 
[14]. Tria Anggraini, D., \& Hasibuan, R. (2020). Gambaran Promosi PHBS Dalam Mendukung Gaya Hidup Sehat Masyarakat Kota Binjai Pada Masa Pandemic Covid-19 Tahun 2020. Menara Medika, 3(1), 22. https://doi.org/10.31869/mm.v3i1.2 194

[15]. Triastami, A. A. (2018). Tindakan Sosial Pedagang Angkringan dalam Penerapan PHBS (Perilaku Hidup Bersih dan Sehat) di Surabaya. Komunitas, 6(1), 23-41.

[16]. WHO. (2021). World Health Organization. WHO Coronavirus (COVID-19). https://covid19.who.int/

[17]. Zukmadini AY. (2020). Edukasi Perilaku Hidup Bersih dan Sehat (PHBS) dalam Pencegahan COVID19 Kepada Anak-Anak di Panti Asuhan. 3 (1), 68-76. 